\title{
Perinatal transmission of Cytomegalovirus (CMV) in children born to HIV positive and negative women in Cameroon
} Anfumbom Kfutwah ${ }^{* 1}$, Mathurin Tejiokem ${ }^{1}$, Albert Faye ${ }^{2}$, Martial Yonga ${ }^{1}$, Josiane Warszawski ${ }^{3}$, Stephane Blanche ${ }^{4}$, Claire Rekacewicz ${ }^{5}$, Francis Ateba ${ }^{6}$, Jean Ndongo ${ }^{6}$, Georgette Guemkam ${ }^{6}$, Chantal Same-Ekobo ${ }^{7}$, Christine Rouzioux ${ }^{4}$, Marianne Leruez-Ville ${ }^{4}$, Pascal Boisier ${ }^{1}$ and Dominique Rousset ${ }^{1}$

Address: ${ }^{1}$ Centre Pasteur, Yaounde, Cameroon, ${ }^{2}$ Hôpital Robert Debré, Service de Pédiatrie Générale, Paris, France, ${ }^{3}$ Unité Inserm U822, CHU de Bicêtre, Bicetre, France, ${ }^{4}$ Hôpital Necker Enfants Malades, Paris, France, ${ }^{5}$ ANRS, Paris, France, ${ }^{6}$ Centre Mère et Enfant de la Fondation Chantal Biya - Maternité Principale Hôpital Central de Yaoundé, Yaounde, France and ${ }^{7}$ Centre Hospitalier d'Essos à Yaoundé, Yaounde, Cameroon

* Corresponding author

from Fifth Dominique Dormont International Conference. Mother-to-child transmitted viral diseases: from transmission to children care Paris, France. 26-28 March 2009

Published: 22 July 2009

Retrovirology 2009, 6(SuppI I):O23 doi:I0.II86/I742-4690-6-SI-O23

This abstract is available from: http://www.retrovirology.com/content/6/SI/O23

(c) 2009 Kfutwah et al; licensee BioMed Central Ltd.

\section{Background}

Cytomegalovirus (CMV) infection is considered as a risk factor in disease progression in HIV co-infected infants. The objective of this study was to evaluate the perinatal transmission of CMV in children born to HIV positive women compare to HIV negative women and to evaluate the prevalence of CMV in HIV infected infants.

\section{Methods}

Children born to HIV positive and negative women who participate in ANRS 12140 survey (Pediacam) in Yaoundé (Cameroon) were included in this study. Whole blood samples were collected from the children at the moment of inclusion into Pediacam. DNA was extracted using the Qiagen blood extraction kit and CMV DNA was quantified using a real time in house CMV PCR (ABI Prism 7700, Applied Bio systems). Two groups of HIV infected children diagnosed before 6 months were included: children followed since birth with early diagnosis (group I; $\mathrm{n}=17$ ) and those not followed since birth and diagnosed generally later (group III; $n=29$ ). There were two groups of HIV uninfected children followed since birth: those born to HIV-infected mothers (group II; $\mathrm{n}=11$ ) and those born to seronegative mothers (group IV; $\mathrm{n}=12$ ).

\section{Results}

Among the 69 children who participated in this study (median age; 15 weeks [range 3-34 weeks]) 31 (45\%) had a positive CMV detection. CMV prevalence was 31 and $65 \%$ in groups I and III respectively and 0 and $64 \%$ in groups II and IV. All infants of group IV were breastfed while the other groups consisted of children who were either breast-fed or bottle-fed. As expected, CMV prevalence was higher in the breastfed children 21/33 (66\%) than in the bottle-fed children $7 / 34(21 \%)\left(\mathrm{P}<10^{-4}\right)$ (Information not available for 2 children.)

There was a $30 \%$ increase in CMV prevalence among HIV infected children compared to non infected children in both the breastfed group ( $81.2 \%$ versus $50 \%$ ) and the bottle fed group (29\% versus $0 \%$ ). The median CMV viral load was 3.6 log copies/ml [range 1.2 to 6.5]. Viral load was higher in group III (4.6 log copies $/ \mathrm{ml}$ ) compared to groups I, II, and IV (3.1, 0, and $2.8 \mathrm{log}$ copies $/ \mathrm{ml}$ respectively) $(P=0.01)$. Among the infants of group III who presented with non specific symptoms, CMV was detected in $12 / 16(75 \%)$. Group III presented subtle differences in CD4 cell percentages between CMV infected and non infected children $23 \%$ vs. $31 \%$. 


\section{Conclusion and perspective}

This preliminary study showed a high incidence of CMV infection in HIV infected infants in Cameroon. As previously described, breastfeeding and HIV transmission irrespective of mode of feeding were associated with CMV infection. Most of the HIV symptomatic children were infected with CMV. This co-infection may be a major factor of morbidity/mortality in children with severe HIV disease in the African setting.

Publish with Bio Med Central and every scientist can read your work free of charge

"BioMed Central will be the most significant development for disseminating the results of biomedical research in our lifetime. " Sir Paul Nurse, Cancer Research UK

Your research papers will be:

- available free of charge to the entire biomedical community

- peer reviewed and published immediately upon acceptance

- cited in PubMed and archived on PubMed Central

- yours - you keep the copyright 